\title{
Predestination and the Exercise of Free Will: An Islamic Reading of Hamlet
}

\author{
Dr. Ahmed T. Hussein \\ Department of English Language \& Translation \\ University of Applied Science \\ P.O. Box: 166, Amman, Jordan 11193
}

\begin{abstract}
Hamlet has attracted many research projects. It has remained Shakespeare's most-analyzed play. The play and its central characters have been the outlines of several critical studies that dealt with the various perspectives of analysis. Many studies tried to examine Shakespeare's religious faith as projected in the play. Some tried to inspect the touches of Shakespeare's Catholic impact on the play. This paper, however, attempts to explore the notion of inevitability and the dictation of fate in the play from the perspective of Islam. Moslems differ in their view of predestination and the understanding of the doctrine of free will from Calvinists and Catholics. Therefore, an Islamic reading of the play would alter the understanding and interpretation of the role fate plays in shaping the action and the destiny of Hamlet, the protagonist as well as the other characters who fall victims to their fates. The study offers an alternative perspective that diverges from the conventional and traditional readings of the play.
\end{abstract}

Keywords: fate; free will; Hamlet; Islam; predestination; Shakespeare.

\section{Introduction}

No writer has ever been the project of extensive research more than William Shakespeare. Shakespeare's Hamlet has attracted many research projects. Hamlet has remained Shakespeare's most famous and most-analyzed play. The play and its central characters have been the topics of several critical studies that dealt with the various perspectives of analysis. A number of works have been devoted to explore Shakespeare's faith both the incorporation of religious reference in his work as well as conjecture about whether he was a Protestant or a Catholic? They have tried to probe into his announced or, otherwise, covered religious inclinations. An invaluable contribution in this respect is Beatrice Batson's Shakespeare's Christianity: The Catholic and Protestant Poetics of Julius Caesar, Macbeth, and Hamlet (2006). The work traces how Catholicism and Protestantism both had had an impact on the three tragedies. Besides attempting to inspect Shakespeare's own religious faith, it more concentrates on different outlines left by Catholic and Protestant traditions that lie behind Shakespeare's creative brilliance.

Another important study is Peter Milward's The Catholicism of Shakespeare's Plays (2000) that examines the traces the influence of Catholicism within Shakespeare's plays, and claims that the plays should be appreciated as works of a playwright whose stance was shaped by the Catholic conviction to which he stayed devoted, and who was genuinely alarmed by the existent tyranny of the Catholic Church in England. In his invaluable work, Piero Boitani suggests that Shakespeare read the New Testament with great care and that "Shakespeare was thinking about a rapprochement between London and Rome." Biotani cites examples from the final scene of Cymbeline, Hamlet, and The Tempest as "veiled hope of a meeting between the papacy and the Crown ". (2014, pp. 2-3).DeGroot (1995) discusses Shakespeare's Catholic background in his The Shakespeare's and "The Old Faith"

Zhang Xuemei (2016, p. 19) comments on what he regards as provoked disputes on Shakespeare's devotion to his Christian faith. Xuemei suggests that despite the fact that Shakespeare lived and wrote in an era when Anglican dominance was prevalent, yet he managed to demonstrate markedly an anti-Calvinistic perspective of Free Will, to be elaborated clearly, that man's will can be reconciled with God's will, that the trail towards infinity and salvation is neither easy nor plain, and that human beings are not saved by virtuous deeds, but by benevolence through belief that operates thoroughly. Among the studies that tried to show Shakespeare's affiliation to religion is Beatrice Groves' study (2006) that makes a close reading to a number of Shakespearean plays and claims that they reveal borrowings from both Catholicism and Protestantism. Similarly, David Kaula (1984) studies references to doomsday in Hamlet. The application of Christian theology to the study of Hamletis discussed by William Hamilton who voices pessimism for the inadequacy every Hamlet critic enters into his task. (1946).

\section{The doctrine of predestination in Hamlet}

The doctrine of predestination and free will is one important topic of scholarly interest. There has been a number of works that tried to focus on linking the play and the characterization of its protagonist to the idea of predestination, inevitability and the exercise of free will. Joseph Milne studies the play and tries to highlight, what he considers "the conflict between fate and grace". Milne argues that Shakespeare seems to be troubled with decisive alternatives of life and death. Milne argues that these ultimate choices "are dramatically framed within the Christian Platonism of the Renaissance". (1992, p. 3) 
Charles K Cannon (1971, p. 204) reads Hamlet in the light of Calvin's "doctrine of predestination". Cannon believes that in Hamlet, Shakespeare makes use of the dramatic exposition as an allegory for the human being's condition who is only predestined to perform in a particular way while being held responsible for his acts.In "Divine Providence in Hamlet", Blackmore (1917) argues that Hamlet, after the murder of Rosencrantz and Guildenstern proved his intellectual sharpness as he realizes more than ever the interpellation of Divine Providence in people's dealings.

John Curran (2006) considers the inner mechanisms of the play against the religious beliefs of the time. Curran delves into how Shakespeare depicts an entirely abstract universe in the "Calvinist mode". Curran views in Hamlet a Catholic Prince ensnared in a Protestant world which steadily forbids his ambitions for a morally decent life. Shakespeare is able in Hamlet, Curran argues, to illustrate the consequences of entirely substitutingonelongstanding religion with a different one. In his forward to Curran's book, Nurnberg states that Curran's reading suggests the:

Hegelian tragic principle of damned-if-you-do, damned-if-you-don't. Damned by Calvinists for trusting the will is free, by Catholics for denying sinners any chance of reformation. Damned if you trust salvation by works and the sacramental order, damned if you don't trust God's providence. Damned if you insist you're saved, damned if you can't find in yourself signs of regeneration. Damned if you believe in human perfectibility, damned if you despair of human redemption. (Curran, 2006, p. v)Jin Tao and Wang Hong-ming's (2006) examine Hamlet's character and try to analyze what they claim as the protagonist's weakness in the perspective of predestination. They maintain that a close reading of the text finds that how and why the Apparition is endowed with a strong impression of predestination. "To set it right" is, therefore, imposed on Hamlet and becomes his unshakable destiny.

Beauregard (2008) argues that Shakespeare views revenge in the context that makes it justified, because Hamlet is charged to act as an agent of justice to stop Claudius from pursuing evil and therefore e ale to cleanse the whole of Denmark of the filth that inflicted it. However, Beauregard also retains the idea that the Shakespeare chose to focus on "delineating the portrait of a reckless and incompetent avenger," one who allows abhorrence to stain his heart.These various studies, among others, are attempts to approach Shakespeare's canon through possibly linking the text to aspects of religiosity it reflects. What is particularly lacking, however, is a reading that will be based on Islamic thought, a reading that would interpret the doctrine of predestination and free will through an Islamic perspective.

\section{Predestination in Islam}

In Islam, predestination is understood as God's divine knowledge of what has already taken place, what is taking place and what is yet to happen. There are several Suras (verses) in The Qur'an that speak of The Almighty's prior knowledge of every single act predestined to take place before the creation of the universe. "But ye will not, unless Allah wills; for Allah is full of Knowledge and Wisdom" (The Qur'an; Sura 76, Al-Insan, Ayah 30). Qadr, or predestination, in Islam basically comes in four stages: Allah's Knowledge, Allah's Prior-Recordings, Allah's Will, and Allah's Creation.

Moslems believe that Allah, the Almighty, has predestined and fated with full knowledge of all events in the world. He continues, at His will, to orchestrate and ordain what is yet to take place in the world. This is brought about by His being all-powerful, all-knowing and all-seeing: "Verily this (The Qur'an) is no less than a Message to (all) the Worlds; (With profit) to whoever among you wills to go straight, but ye shall not will except as God wills; the Cherisher of the Worlds." (The Qur'an; Sura 81, Al Takwir, Ayahs 27-29).

A Moslem is not a true believer unless s/he believes that nothing happens in the universe except by the will of Allah as the creator of all things, Allah knows what is to come and He decreed all of that and wrote it in the Book of Decrees (Al-Lawh Al-Mahfooth) before creating the heavens and earth: "Verily, We have created all things with Qadar (Divine Preordainments) of all things before their creation as written in Al-Lawh Al-Mahfooth (the Book of Decrees)". (The Qur'an; Sura 54, Al Qamar, Ayah 49)Allah has a prior knowledge of any calamity that may inflect human beings before it happens:"No misfortune can happen on earth or in your souls but is recorded in a decree before We bring it into existence: That is truly easy for Allah.”(The Qur'an; Sura 57, Al Hadid, Ayah 22). Moslems, equally, believe that the Almighty is Kind, Gracious and constantly Just. Allah never wrongs anyone in the slightest, because He is independent of His creation and has no need of them. The limit of an individual's life is deliberated by Allah so is one's fortune: good or bad. However, Allah puts no pressure on human beings to keep to the straight path. Allah does not interfere in one's will:"It is true thou wilt not be able to guide every one (3388) whom thou lovest; but Allah guides those whom He will and He knows best those who receive guidance." (The Qur'an; Sura 28, Al-Qasas, Ayah 56)

Moslems, however, also believe that the Almighty has given the human being the freedom of choice throughout one's life. Still, there are some people who think that the freedom of choice given to man conflicts with the consent of Allah in His universe, which is very far from the truth: 
"For Allah leaves to stray whom He wills, and guides whom He wills" (The Qur'an; Sura 35, Fatir, Ayah 8).A Moslem believes in the principle that Allah allows Man to do righteous deeds by his own choice and free will, then he is granted Paradise, or do evil deeds by his own choice and free will, then he enters Hell:"Verily, We showed him the way, whether he be grateful or ungrateful"(The Qur'an; Sura 76, Al Insaan, Ayah 3)."Then shall anyone who has done an atom's weight of good, see it! 8. And anyone who has done an atom's weight of evil, shall see it." (The Qur'an; Sura 99, Al Zalzalah, Ayahs 7-8).

Sheikh Mohammed Mutwli AlSharawi (1975, p. 45), an Islamic scholar, states that Moslems believe that Allah exercises His will in His creation and that nothing is exempted from His decree. But Moslems similarly believe that people, themselves, cause their own destruction. Hence, they become worthy of the punishment or the mercy of Allah based on their accounts. In the Qur'an, it is stated that: "Verily Allah will not deal unjustly with man in aught; it is man that wrongs his own soul" (The Qur'an, Sura 10, Yunus, Ayah 44).

In his book, The Qur'an: An Attempt Towards a Modern Understanding, Mustapha Mahmoud (1999, p. 26) suggests that humans' freedom is determined by Allah's will, wish and intention. Allah refused to force human beings upon belief. Instead, human being are given the choice: choosing between belief and disbelief:"If it had been thy Lord's will, they would all have believed,- all who are on earth! wilt thou then compel mankind, against their will, to believe! The Qur'an; Sura 10. Yunus (Jonah), Ayah 99)

\section{Reading Hamlet: An Islamic Perspective}

The Catholic and the Calvinist Churches meet and diverge with regard to the idea of Predestination and free will. While the Catholic Church advocates that human beings are free to do good or evil, Protestants believe are free only to do evil. Pertaining to Predestination, Catholics stress that it is related to God's foreknowledge. Protestants link it to God's decrees.

This paper approaches Shakespeare's play from the Islamic perspective, attempting to examine how the protagonist's fate could be analyzed through Islamic lenses stressing how this departs sharply from the conventional studies of the play. Seen from this angle, the doctrine of fate and predestination as deployed in Hamlet could be interpreted differently from the conventional Christian spectacles. Right from the few pages that open the play, Hamlet's fate is made prominent in determining the main action of the narrative and hence, dictation the protagonist role.

At the outset of Hamlet, Horatio seems to be convinced that the emergence of the late king's apparition is a shocking herald, very much analogous to that day in Rome, shortly prior to the time when "the mightiest Julius fell" when "the graves stood tenantless and the sheeted dead / Did squeak and gibber in the Roman streets" (1.1. 115-116). Horatio, immediately, ponders on the imminent risk "fate" constitutes as a kind of calamity looming over Denmark. When the apparition appears on the platform, Horatio tries to confront it, urging: "If thou art privy to thy country's fate, / Which, happily, foreknowing may avoid, / O speak!" (1.1.133-135). Horatio is proposing that the apparition's visit could be to acknowledge something sinister befalling the whole nation. This suggests that fate is avoidable, not inevitable.

An Islamic reading of the same scene would consider the timing of the appearance of the apparition is never haphazard. It purports that this is an exquisitely timed event that would lead to the actions that would dictate the protagonist's end. A Moslem would unequivocally dismiss the notion that fate could be altered by any force other Allah the Almighty who determines, designs, and orchestrates the fate of the whole universe. Everything in this world, whatever it is and what it will be, has been decreed by God in his book, and has known it, and has willed it. This is Qadre (destiny) in its four orders: writing, knowledge, will, and adding to the created and creation. Allah is knowledgeable of all. No will is above His: "With Him are the keys of the unseen, the treasures that none knoweth but He. He knoweth whatever there is on the earth and the sea. Not leaf doth fall but with His knowledge: there is not a grain in the darkness [or depths] of the earth, nor anything fresh or dry [green or withered], but [inscribed] in a record clear [to those who can read]. (The Qur'an, Sura 6, Ayah 59).

In Act 1, Scene 4, Hamlet comments on his uncle's carousing, pointing out how one immoral instance could damage the reputation of a whole nation. He broods over the philosophical notion of how evil and corruption inflict people conjuring up that the source of evil could be "carrying the stamp of one defect/being nature's livery, or fortune's star" (31-32). Hamlet suggests that some people are born with the flaw while others develop one as they grow. He is purporting that some faults just happen to people rather than something they deliberately choose to happen. A Moslem viewer of such a thesis would dismiss this. A Moslem reader will wholly believe in personal deliberation and choice rather than being a victim of circumstance where self-choice will be terminated. It is a freedom of choice, Moslems hold, which is entirely predestined and ordained by Allah's foreknowledge: "As to the Thamud, We gave Guidance, but they preferred blindness [of heart] to Guidance: so the stunning Punishment of humiliation seized them, because of what they had earned." (The Quran, Sura 6, Ayah 59). Within the same scene, and in a similar context, Hamlet decides to follow the apparition who is beckoning him to a remoter spot. 
Horatio and Marcellus try to deter him from following the apparition. Hamlet rejects his friend's plea exclaiming: "My fate cries out, / And makes each petty artery in this body / As hardy as the Nemean lion's nerve" (1.iv.8183).He suggests that he is fated to answer the apparition's call.

This, correspondingly, is interpreted by a Moslem reader as a negation of personal choice when the will-less character is depicted as a victim to the dictation of his own qadar. Moslems as much as they believe in the doctrine of predestination, equally believe in the human freedom of choice. This seems to be missing in Hamlet's blind devotion to the instructions of the apparition and his equation between the venture of meeting rather anonymous apparition and following an unknown fate:"No kind of calamity can occur, except by the leave of Allah: and if any one believes in Allah. [Allah] guides his heart [aright] for Allah knows all things." (The Qur'an, Sura 64, Ayah 11). In Act II, the First Player, while reciting the lines Hamlet has prepared, speaks of Fortune as a whore. The lines describe the merciless killing of "old grandsire Priam" at the hands of "hellish Pyrrhus":

Out, out, thou strumpet, Fortune! All you gods,

In general synod take away her power;

Break all the spokes and fellies from her wheel,

And bowl the round nave down the hill of heaven,

As low as to the fiends! (2.2.451-455)

The plea to the gods, here, is to rob Lady Luck of all her powers as it stands beside the wheel keeping it spinning as those on top would be thrown off into the depths of hell. The scene implies that fate is simply arbitrary, and human beings are deceived to think other than that. The First Player's speech requests the gods to alter all, so that the world will be controlled by validity, not fortune.A Moslem's understanding of the scene is that human fate is predestined before the birth of the individual and set by the Creator. Predestination is preordained and even when it is altered, it is so by the will of God and His prior knowledge. Prophet Mohammed says:

"Each one of you collected in the womb of his mother for forty days, and then turns into a clot for an equal period (of forty days) and turns into a piece of flesh for a similar period (of forty days) and then Allah sends an angel and orders him to write four things: his provision, his age, his work, and whether he will be of the wretched or the blessed (in the Hereafter). Thenthe soul is breathed into him. And by Allah, a person among you may do deeds of the people of Fire till there is only a cubit or an arm-breadth distance him and the Fire, but then that writing (which Allah has ordered the angel to write) precedes, and he does the deeds of the people of Paradise and enters it; and a man may do the deeds of Paradise till there is only a cubit or two between him and Paradise and then that writing precedes and he does the deeds of the people of the Fire and enters it." (Sahih ai-Bukhari, 3208).

There is no change to what is contained in the Book of Decrees (Al-Lawh Al-Mahfooth), nor a change in the knowledge of God. Allah knows that he will do so, and he will recover or increase his age. These are: what is in the Book of Decrees, and what is in the knowledge of God, There is no change to it. In another important scene that shows the protagonist's adherence to predestination and the absence of free will, Hamlet addresses Horatio with references the possibility of putting himself in danger in accepting the fencing-match with Laertes: "We defy augury. There's a special providence in the fall of a sparrow. If it be now, 'tis not to come. If it be not to come, it will be now. If it be not now, yet it will - the readiness is all. Since no man of aught he leaves knows, what is't to leave betimes? Let be," $(4,2,192-196)$

Hamlet's words reflect his belief that if he to fall, then it will be only to the decree and direction of Providence. This is probably the most quoted passage from the play to illustrate Hamlet's and, therefore Shakespeare's, belief in predestination. Zhang (2016, p. 25) suggests that "let be" repeated twice by Hamlet to Horatioin the closing scene of the play establishes "his indifference to almost all worldly things - throne, honor, love, life - and his calmness to face the necessity and fairness of death".

Once again, a Moslem reader of the same excerpt would agree with Hamlet's belief in the doctrine of predestination but equally, this reader believes that the Almighty gives human beings the free will to choose with the Providence's prior knowledge of the many choices human beings are to decide upon. The excerpt, viewed with Islamic lenses, would be interpreted first and foremost as Hamlet's own choice rather than his lack of personal will or him being victim of some ruthless fate.

There is no contradiction, in Islam, between the belief that deeds are predestined or preordained and the idea that we are free in fulfilling these deeds: We do not know what is written, but we feel the full freedom and choice in action, and distinguish between forced movement such as the movement of the heart and intestines, and the optional movement we do with hands, legs, eyes or otherwise. Therefore, people are accountable for their actions, because they act by their choice. The individual can do good as s/he can to do evil, and s/he has no right to argue that it is written on him/her as such, because s/he does not know what is written until after it has occurred, and s/he does not know the end of it. It may have been decreed that a person might commit evil and then redeem and ask Allah forgiveness. If this happens, it so happens with Allah's prior knowledge. 
Moslems believe that the role assigned to the created is to work sincerely in the path that leads to Paradise and avoid sins and never rely on wishes that Allah might have preordained Heaven regardless of genuine deeds leading to His Blessings:

"No misfortune can happen on earth or in your souls but is recorded in a decree before We bring it into existence: That is truly easy for Allah. In order that ye may not despair over matters that pass you by, not exult over favours bestowed upon you. For Allah loveth not any vainglorious boaster". (The Qur'an; Sura 57, Ayah 22-23).In an important scene which is exemplified as the illustration of how fate dictates the action of the protagonist is the incident of Hamlet's ordeal with the pirates in Act IV. Horatio informs how Hamlet has escaped death. Horatio learns from Hamlet's letter how the latter was saved by pure intervention of fate and managed to return safe to Denmark after Claudius's plan that would have guaranteed his death in England. The letter, Horatio receives, explains how Hamlet met the pirates while at sea who ironically rescued him and helped him return to Denmark in return for a favor.

This has always been quoted to demonstrate how much fate dictates actions, swerve ends and twist others. Elmer Edgar Stoll (1919, p. 74), for instance, views that scene as an illustration of how Hamlet "takes his fate into his own hands". The failure of Claudius's otherwise well planned scheme, Hamlet's change of fortune and his ultimate return and the death of Rosencrantz and Guildenstern are but the interpolations of fate which drove these pirates to Hamlet only to rescue him and help him go back to Denmark in order to pursue the quest of avenging his father's death. A Moslem reviewer would regard the scene with the understanding that nothing is haphazard. Rather everything is predestined but with the prior knowledge of Allah the Almighty who knoweth all:

"With Him are the keys of the unseen, the treasures that none knoweth but $\mathrm{He}, \mathrm{He}$ knoweth whatever there is on the earth and in the sea. Not a leaf doth fall but with His knowledge: there is not a grain in the darkness [or depths] of the earth, nor anything fresh or dry [green or withered], but is [inscribed] in a record clear [to those who can read]." (The Qur'an; Sura 6, Ayah 59).Hamlet expounds on the doctrine of predestination and inevitability in Act 4, scene 2. Earlier, he had informed his trusted friend Horatio his feelings of bitterness with regard to the "innocent" fencing match. He states in plain words that he feels obliged go on and fight as he is fated to albeit his ill feeling about it. He says that no matter what his decision and action would be like, everything is bound to happen as all rooted in fate.

Hamlet seems to suggest that humans are helpless since what is predestined to be is going to be and, hence, he is suggesting the total absence of personal will. Ultimately, nothing can be done. He feels fated to go for the fencing match which would consequently lead to his own downfall. Fate, to Hamlet, would ultimately have its way, no matter how one tries to meddle with it. A Moslem reviewer of the same quote would comprehend the notion of inevitability of actions but would not accept negating the exercise of personal will projected above by Hamlet's tone: "Allah is He Who created seven Firmaments and of the earth a similar number. Through the midst of them [all] descends His Command: that ye may know that Allah has power over all things, and that Allah comprehends, all things in [His] Knowledge". (The Qur'an; Sura 65, Ayah 12).

The same understanding could be applied to Hamlet's important statement commenting about the fate that lead to the demise of Rosencrantz and Guildenstern: There's a divinity that shapes our ends, Rough-hew them how we will

(Act 5, Scene 2, 11-12) Hamlet is acknowledging that not everything is in our control, and that ultimately God is who determines all outcomes. Shakespeare suggests that a divine power that resolves our fate. It is not us who decide. Shakespeare expresses this view in the words of the Player King in the famous play within the play:

"Our wills and fates do so contrary run

That our devices till are overthrown.

Our thoughts are ours, their ends none of your own."

(Act 3, Scene 2, 223-225)

Xuemei Zhang uses the above excerpt to demonstrate what he claims Shakespeare's "incapability" to link between the teachings of Catholics and Anglicans. Zhang (2016) suggests that: "Deeply affected, we often muse on the mishaps of the heroes struggling in all inscrutable forces and uncontrolled sufferings, Based on incomprehensible grace of God and unpredictable Providence, God's select and salvation is found the most puzzling ultimate mystery, which proves a question so challenging that it goes beyond the capability of Shakespeare, lost from time to time between the propaganda of Catholic teaching and of Anglican teaching, to judge and settle demonstrably. (p. 26) Islam agrees with this idea. However, Islam also stresses that actions taken in the right path could alter one's fate. Free will cannot be denied:"Verily We created Man from a drop of mingled sperm, in order to try him: So We gave him [the gifts of], Hearing and Sight. we showed him the Way: whether he be grateful or ungrateful [rests on his will]. For the Rejecters we have prepared chains, yokes, and a blazing Fire. as to the Righteous, they shall drink of a Cup [of Wine] mixed with Kafur, A Fountain where the Devotees of Allah do drink, making it flow in unstinted abundance." (The Qur'an, Sura 76, Ayahs 3-6)In more than one instance in the play, Hamlet struggles with the task of understanding fate and its mysterious power over life. In the famous soliloquy, Hamlet states: 
"To be, or not to be: that is the question:

Whether 'tis nobler in the mind to suffer

The slings and arrows of outrageous fortune,

Or to take arms against a sea of troubles,

And by opposing end them?" (Act 3, Scene 1, 55-59)

It is the sense of perplexity, the uncertainty about his fate, whether or not he should take his fortune into his own hands or alternately continue to live a despicable life and bend to the storm and endure the pain within. In Act III, after stabbing Polonius, Hamlet stands over the body and says: "Take thy fortune, Thou find's to be too busy is some danger." (Act 3, Scene 4, 32-33) Hamlet suggests that Polonius, who has always poked his nose and intervened begging the favours of the King deserves his fate. Sarcastically, Hamlet is suggesting that Plotinus's "fortune" is well deserved because he has tried throughout to plant himself in the wrong place at the wrong time Hamlet views Polonius's death as a punishment, a scheme and part of heaven's plan which cannot be avoided or altered:

$$
\begin{aligned}
& \text { "For this same lord, I do repent: } \\
& \text { but heaven hath pleased it so, }
\end{aligned}
$$

Top punish me with this and this and this with me,

That I must be their scourge and minister" (Act 3, Scene 4, 172-172)

The "bloody" scenes by the end of the play when several characters, including, the protagonist, are simultaneously killed, have always been interpreted to be the working of fate in Hamlet and the extent of the role it plays. Gertrude insists on drinking from a poisoned cup in honor of her son's success at the outset of the fencing match with Laertes. Laertes, himself, falls after being injured by the treacherous rapier has enough breath left to announce "the King's to blame", prompts Hamlet to stab the King after declaring: "The point envenomed too! _ Then, venom, to thy work!" All these killings certainly support the idea of how much these deaths are predestined and that providence is at work. Traditionally, these deaths are understood as exemplifications of divine justice. A Moslem understands these deaths supported by the belief: "They plot and plan, and Allah too plans; but the best of planners is Allah". (The Qur'an, Sura 8, Ayah 30) to grasp the mysterious power that controls the universe.

\section{Conclusion}

Shakespeare will always invite fresh studies and Hamlet will always pose a challenge to scholars. The concept of predestination and the exercise of free will is an ongoing open debate to Christians and Moslems alike. This study has tried to demonstrate that an Islamic reading of Hamlet is exceptionally different from conventional readings of Shakespeare's work especially when it attempts to examine the role fate plays in determining the action and dictating the fortunes of characters. Orthodox interpretations of the play might present the characters as victims. An Islamic reading would offer a significant alternative.

Scholars have not been able to determine the Bard's personal religious affiliation (Cox 2018). So far, there has been several attempts to investigate the possibility of linking Islam to Shakespearean canon. However, the question whether or not Shakespeare has, indeed, been aware of Islam as a religion is an enterprise for an interesting further study that would certainly contribute to alternative understandings of Shakespearean works.

\section{References}

Ali, Abdullah Yusuf. 1997. The Meaning of the Qur'an. Amana Publications.

Al-Bukhara, Imam Ismail. Sahih al-Bukhara. Digital Deen Publications. May 18, 2017.

AlSharawi, Mohammed Mutwli. 1975. Al-Qaida' wa Al Qatar (Fate and destiny). Cairo: Dar Al Shorooq.

Batson, Beatrice, ed. 2006. Shakespeare's Christianity. The Protestant and Catholic Poetics of Julius Caesar, Macbeth and Hamlet. Waco TX: Baylor University Press.

Boitani, Piero. 2014. The Gospel According to Shakespeare. University of Notre Dame Press

Blackmore, Simon Augustine. 1917. The Riddles of Hamlet and the Newest Answers. Boston, Stratford Co.

Cannon, Charles K. (1972) "As in a Theater": Hamlet in the Light of Calvin's Doctrine of Predestination", in Studies in English Literature 1500-1900 11(2):203 - September 1972

Cox, John. 2018. Shakespeare and Religion. Religions 9: 343.

Curran Jr., John E. 2006. Hamlet, Protestantism, and the Mourning of Contingency: Not to Be. Rutledge.

De Groot, John Henry 1995. The Shakespeare and 'The Old Faith'. Real-View Books

Groves, Beatrice. 2006. Texts and Traditions - Religion in Shakespeare 1592-1604 UK; OUP.

Hamilton, William .1964. "Hamlet and Providence" in The Christian Scholar. Vol. 47, No. 3. FALL, 1964, pp. 193-207. Penn State University Press. 
Jin Tao, Wang Hong-ming. 2006. "Why Can Hamlet Neither Put It Down, Nor Shoulder It?_—_An Interpretation of "Weakness" in Hamlet's Character from Perspective of Predestination", Journal of Jiangsu University of Technology, 03, Changzhou 213001, China.

Kaula, David. 1984. "Hamlet and the Image of Both Churches", in Studies in English Literature, 1500-1900. Vol. 24, No. 2, Spring, 1984, pp. 241-255. Rice University

King, Peter. 2010. Augustine: On the Free Choice of the Will, On Grace and Free Choice, and Other Writings (Cambridge Texts in the History of Philosophy). New York: Cambridge University Press

Mahmud, Mustapha. 1999. The Qur'an: An Attempt Towards a Modern Understanding. Cairo: Dar elMa'aref.

Millard, Peter. 1997. The Catholicism of Shakespeare's Plays. London: Saint Austin's Press.

Millard, Peter. 1973. Shakespeare's Religious Background. London: Sedgwick \& Jackson.

Mutschmann, Heinrich and Karl Wentersdorf. 1952. Shakespeare and Catholicism. London: Sheed \& Ward.

Schumann, David. 2013. Conscience Does Make Cowards of Us All. Hamlet the Skeptic Thinker - An Anti-Hero? Germany: Grin Verlag.

Sterrett, Joseph. 2012. The Unheard Prayer: Religious Toleration in Shakespeare's Drama. Leiden, Boston: Brill.

Stoll, Elmer Edgar. 1919. Hamlet: An Historical and Comparative Study. Minneapolis, University of Minnesota.

Taylor, Dennis and Beauregard, David N. 2003. Shakespeare and the Culture of Christianity in Early Modern England. Fordham University Press

Wang, J. F. 1995. "Predestination and the Cultural Tradition of the West". Journal of Historiography, 6, 78-81.

Waters, Douglas. 1994. Christian Settings in Shakespeare's Tragedies. N.J.: Farleigh Dickinson University Press

Yates, Frances A. 1979. The Occult Philosophy in the Elizabethan Age. London: Rutledge.

Zhang, Xuemei. "The Will Not in Bondage: An Interpretation of Free Will in Shakespeare's Pure Tragedies". Studies in Literature and Language. Vol. 12, No. 1, 2016, pp. 19-26.

The author would like to acknowledge the generous funding of the paper by the Applied Science University, Jordan. 